\title{
Artificial and Biological Particles in the Springtime Atmosphere
}

\author{
Chang-Jin Ma* and Ki-Hyun Kim ${ }^{1)}$ \\ Department of Environmental Science, Fukuoka Women's University, Fukuoka 813-8529, Japan \\ ${ }^{1)}$ Department of Environment \& Energy, Sejong University, Seoul 143-747, Korea \\ *Corresponding author. Tel: +81-92-661-2411, E-mail: ma@fwu.ac.jp
}

\begin{abstract}
This study focused on a comprehensive and detailed interpretation for the springtime air quality influenced by both artificial (particulate matter (PM) and asbestos) and biological (pollen) sources in Fukuoka Prefecture, Japan. An intensive measurement of PM was conducted at four characteristic sites (i.e., a heavy traffic area, a residential area, an industrial area, and a desolate area) in the Fukuoka Prefecture during spring of 2007. Analysis of major ionic species in $\mathrm{PM}_{2.5}$ was performed by an Ion Chromatography, and asbestos and pollen were identified by Scanning Electron Microscopy with an energy dispersive $\mathrm{X}$-ray spectrometer (EDX). $\mathrm{PM}_{2.5}$ concentration $\left(65.3 \mu \mathrm{g} \mathrm{m}^{-3}\right)$ measured in an industrial area (site $\mathrm{C}$ ) was extraordinarily high compared to those monitored in other areas; it greatly exceeded the Japan's $\mathrm{PM}_{2.5}$ criteria (a daily average of $35 \mu \mathrm{g} \mathrm{m}^{-3}$ ). NOAA's HYSPLIT dispersion model suggests that this high level of $\mathrm{PM}_{2.5}$ monitored at site $C$ is unlikely to affect the Asian continent. The ambient concentrations of $\mathrm{PM}_{2.5}$-related anions $\left(\mathrm{NH}_{4}{ }^{+}, \mathrm{NO}_{3}{ }^{-}\right.$, and $\left.\mathrm{SO}_{4}{ }^{2-}\right)$ and their relative contributions to $\mathrm{PM}_{2.5}$ were also investigated in four study areas. The concentrations of these major watersoluble ions exhibit not only strong spatial dependence but also different ratios to each other. Asbestos fiber (crocidolite and amosite) concentration values changed in the range of 2.5 to $14.4 \mathrm{f}$ per liter of air. The number of pollen grains showed that Cedar ranked higher in concentration than other types of pollen, with the maximum concentration at site $A$.
\end{abstract}

Key words: Springtime atmosphere, Particulate matters, Asbestos, Pollen, Fukuoka Prefecture

\section{INTRODUCTION}

In urban areas including smaller towns, the presence of ambient artificial particulate matters (PM) (e.g., aged fine PM and asbestos) and allergenic biological pollens has been one of the main causes of adverse effects on human health and air quality. In Japan, there is peculiar annual variation in these ambient PM due to the sources as well as the changing weather. Most synergistic effects take place during spring because of windborne pollen from trees, especially Japanese cedar trees.

From 1949 to 1970, a large number of Japanese cedar trees were planted in many parts of Japanese Island because of a great demand for new housing after World War II. Planted cedar forests now cover $12 \%$ of Japan's total land area, which is more than $45,000 \mathrm{~km}^{2}$. Vast amounts of pollen, especially from cedar trees, drifts over wide areas every spring (Takahashi et al., 1992). As a result, more and more Japanese over the last 30 years have been affected by pollen allergies.

The air quality in urban area, especially its $\mathrm{PM}_{2.5}$ (less than $2.5 \mu \mathrm{m}$ in aerodynamic diameter) level, has become of increasing public concern because of its importance and sensitivity related to health risks (Schwartz and Neas, 2000). This inhalable $\mathrm{PM}_{2.5}$ is generally emitted from both natural (e.g., volcanic eruptions, forest fires, etc.) and anthropogenic sources (combustion processes in industrial sector and automobiles), and it can also be formed when gases react in the air. Inhalable particles, particularly $\mathrm{PM}_{2.5}$, have been demonstrated to have the greatest impact on human health, visibility reduction, and solar radiation change, especially in densely populated urban areas.

Asbestos, a naturally occurring fibrous mineral, can be found naturally in the outdoor atmosphere and in some drinkable water, including water from natural sources around the world (Cook et al., 1974). As asbestos had been a popular building material since the 1950 s, it is still found in many buildings, including hospitals, schools and homes. Inhaling asbestos fibers is known to cause several serious and even fatal lung diseases. Studies have shown that the non-occupationally exposed population have 10,000-999,999 asbestos fibers in each gram of dry lung tissue, which translates into millions of fibers and tens of thousands of asbestos bodies in every person's lungs (Camus et al., 1998). 
However, most building material products manufactured today do not contain asbestos. In the industrialized countries, asbestos was phased out of building products mostly in the 1970s, with most of the remainder phased out by the 1980s (Lemen, 2004). In 2006, the Japanese Ministry of Health, Labour and Welfare issued a final ruling banning most asbestos-containing products with the exception of 5 kinds of materials (e.g., some sealing materials). Those 5 unbanned materials were also banned eventually in 2011. Ever since its initial phase out in 2006 and permanent ban in 2011, it can still be found today in some older buildings and consumer goods. Ambient asbestos fibers will finally be lost in the air and eventually precipitate on the ground. These pieces of asbestos are likely to settle on the soil but can be re-released again into the atmosphere (Monthly Archives, 2013).

To assess the impact of both artificial and biological PM on the environment, including air quality, ecosystems, and human health, it is necessary to know its concentration, chemical composition, and the interplay among their components. The ambient outdoor PM in urban areas has seldom been evaluated with respect to both artificial and biological components. In light of this situation, we undertook a field campaign to evaluate the artificial and biological PM in an urban environment in Japan during springtime.

\section{MATERIALS AND METHODS}

\section{1 Description of Fukuoka Prefecture}

Fukuoka Prefecture is located on Kyushu Island, Japan's third largest island, located southwest of the main island, Honshu. According to the latest estimates (June 1, 2013), its population and total area are $5,088,480$ and $4,971 \mathrm{~km}^{2}$, respectively (Fukuoka Prefecture, 2013).

Fukuoka Prefecture faces the sea on three sides, bordering on Saga, Oita, and Kumamoto prefectures and facing Yamaguchi Prefecture across the Kanmon Straits. Fukuoka Prefecture includes the two largest cities on Kyushu, Fukuoka and Kitakyushu, and much of Kyushu's industry. Fukuoka prefecture's main cities form one of Japan's main industrial centers, accounting for nearly $40 \%$ of the economy of Kyushu. Major industries include automobiles, transport equipment, electronic parts and machine, general machinery, iron and steel, semiconductors, steel, and food (Nussbaum, Louis-Frédéric, 2005).

\section{2 Sampling and Monitoring of Ambient PM}

An intensive measurement of PM was conducted at four selected sites (A: $33.65^{\circ} \mathrm{N} ; 130.45^{\circ} \mathrm{E}, \mathrm{B}: 33.63$

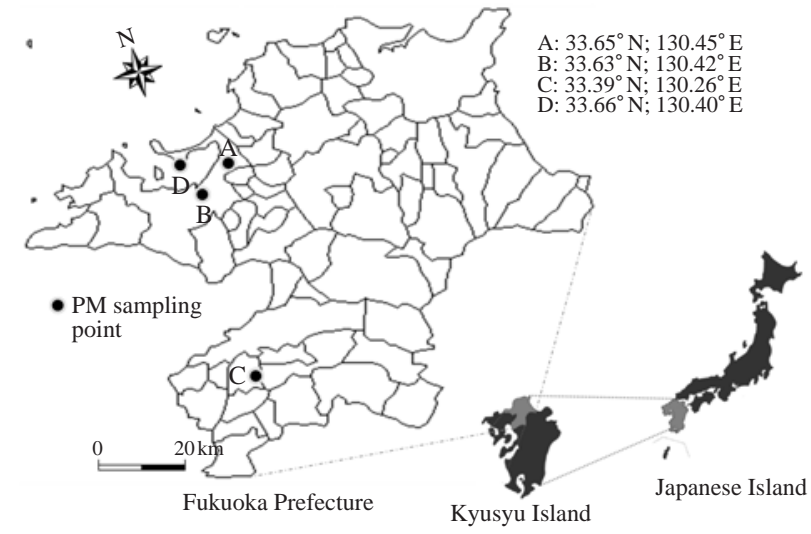

Fig. 1. Locations of sampling stations for PM in Fukuoka Prefecture.

${ }^{\circ} \mathrm{N} ; 130.42^{\circ} \mathrm{E}, \mathrm{C}: 33.39^{\circ} \mathrm{N} ; 130.26^{\circ} \mathrm{E}, \mathrm{D}: 33.66^{\circ} \mathrm{N}$; $130.40^{\circ} \mathrm{E}$,) in the Fukuoka Prefecture. The location of each sampling site in Fig. 1 is indicated by filled circles.

Site A has six-lane roads with heavy traffic conditions. Site B is a residential area and surrounded by a residential area without any known point sources. Site $\mathrm{C}$ is an industrial area with roughly 60 manufacturing companies including small-to-medium sized enterprises. Most of them are distributed within a radius of one kilometer from site C. Site D is a desolate area with resort beach without the influx of people, as our study was conducted during an off-season period.

An intensive measurement of PM was simultaneously conducted at four-sites for two days beginning on April 18, 2007 and ending in April, 2007. For the sampling of size-classified PM, four filter pack samplers were simultaneously operated using a $47 \mathrm{~mm}$ diameter Nucleporefilter ${ }^{\circledR} . \mathrm{PM}_{2.5}$ and PM larger than $2.5 \mu \mathrm{m}$ were collected at the first and second stage of the sampler, respectively. This filter pack sampler consists of a Teflon-coated aluminum cyclone with a cut size of 2.5 $\mu \mathrm{m}$ at a flow rate of $10 \mathrm{~L} \mathrm{~min}^{-1}$ (URG, USA).

In order to assess $\mathrm{PM}_{2.5}$ mass concentration, 4 Dust scan Scouts (Rupprecht \& Patashnick Co. Model 3020) were simultaneously operated at each site. This $\mathrm{PM}_{2.5}$ monitoring system makes use of near-forward light scattering to measure the concentration of particulate matter in ambient air. The light source is a safety-interlocked laser that operates at a wave length of $670 \mathrm{~nm}$. The scattered light caused by the presence of particles is received by a sensor, forming the basis of the monitor's computations. During sampling period, there was no Asian dust event. The wind speed was measured at $2.4-4.7 \mathrm{~m} \mathrm{~s}^{-1}$, with the temperature at around $11.2-$ $19.4^{\circ} \mathrm{C}$ and the average relative humidity at $56 \%$. 


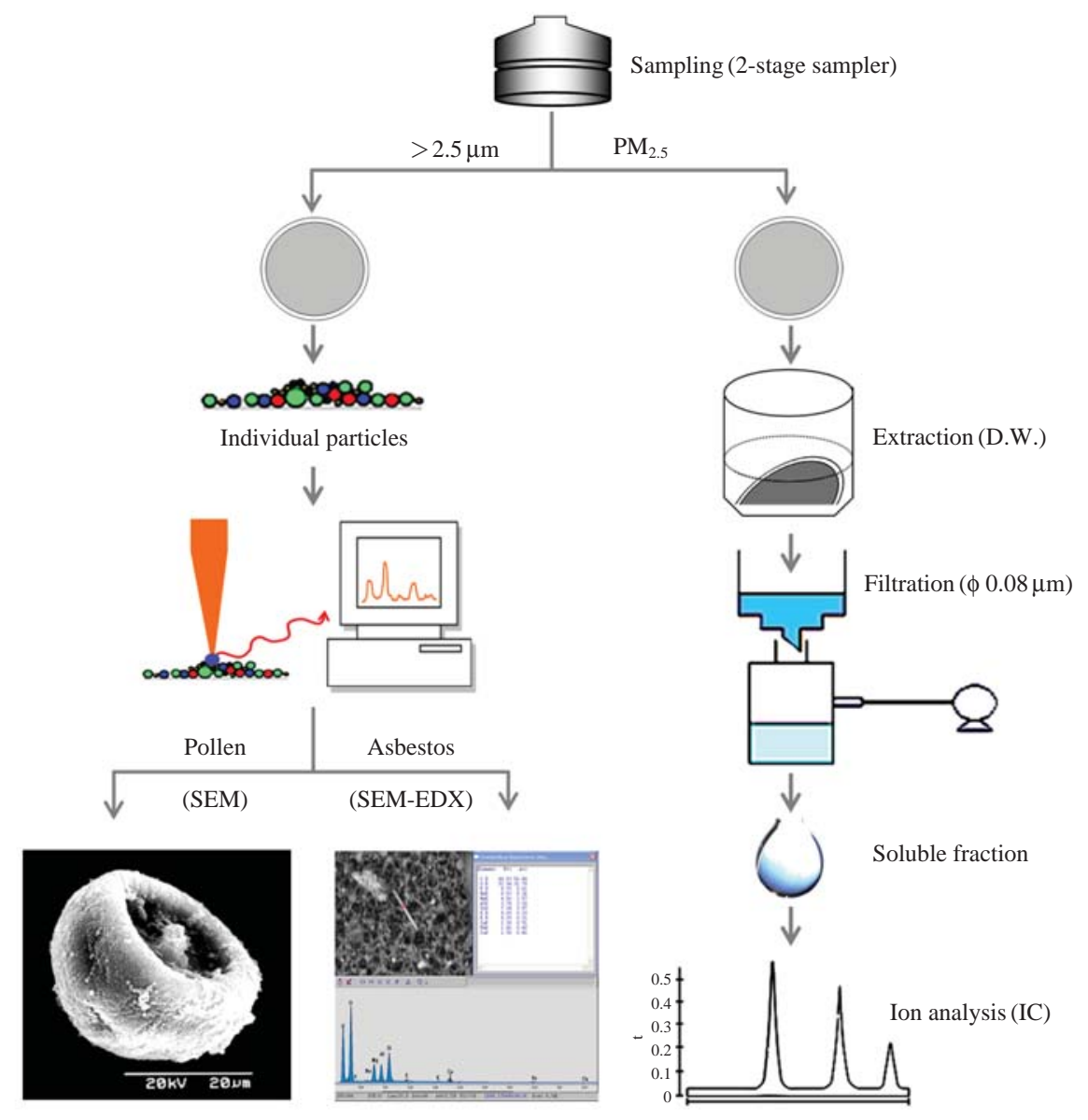

Fig. 2. Procedures of sample pretreatment and analysis.

\section{3 Sample Pretreatment and Analysis}

\subsection{Sample Pretreatment}

After sampling, filters were placed in sterilized airtight petridishes and stored in a refrigerator until analysis. For the laboratory analysis, the filters capturing $\mathrm{PM}_{2.5}$ were extracted with deionized water by ultrasonic treatment. And then the extracted water was filtrated through a $25 \mathrm{~mm}$ diameter Nuclepore ${ }^{\circledR}$ filter with $0.08 \mu \mathrm{m}$ pore size to separate into the soluble and insoluble fractions. After filtration, the filtrate was considered to be soluble fractions. Blank filters were handled in the same manner as the samples.

Meanwhile, the coarse particles $(>2.5 \mu \mathrm{m})$ deposited on the second sage were progressed to single particle analysis for identification of asbestos and pollen. Samples for observation of pollen were coated with a very thin layer of platinum by a machine called a sputter coater.

\section{3. 2 Analysis of Major lonic Species in $\mathbf{P M}_{2.5}$}

In general, sulfate, nitrate, and ammonia had the gr- eatest ambient concentrations in particles (Gao et al., 2013; Deshmukh et al., 2011). The concentrations of major ions in $\mathrm{PM}_{2.5}$ (ammonium, nitrate, and sulfate) were determined by Ion Chromatography (IC) (Dionex DX-100). To attain the reliability of the analyzed data, the quality assurance and quality control (QA/QC) was conducted by analyzing a set of known standard species. The data obtained by 5 -time repeated IC analyses were tested for precision by checking the relative standard deviation (\% RSD, (SD/mean) $\times 100)$ of each concentration in standard solution $(0.5,2$, and $5 \mathrm{mg} / \mathrm{L})$. As a result, all three ionic species maintained low \% RSD levels (i.e., ammonium: 4.63-7.59\%, nitrate: 0.04-9.03\%, and sulfate: $1.96-9.72 \%$ ). This high reproducibility is a clear indication of a methodological soundness.

\section{3. 3 Identification of Asbestos and Pollen}

The most common method of identifying asbestos fibers in ambient PM is by polarized light microscopy. However, a Scanning Electron Microscopy (SEM) can be also usefully applied to the observation of asbestos. The advantage of using a SEM for asbestos identifica- 
tion is that it has better resolution through higher magnification and a greater depth of focus than polarized light microscopy. Most of all, a SEM equipped with an energy dispersive X-ray spectrometer (EDX) (i.e., SEM-EDX) can quantify the elemental components in asbestos. Using an EDX and a computer system, information about the elemental properties of asbestos fibers can be gathered and graphed in their appropriate relative ratios. Computation of the exact ratios of the elemental compositions in asbestos fiber allows the researcher to distinguish not only one type of asbestos fiber from another but also asbestos fibers from nonasbestos fibers.

In this study, for the purpose of observing and analyzing the morphological and chemical properties of airborne asbestos and pollen grains, an SEM (JEOL JSM-5400) equipped with an EDX (Philips, EDAX DX-4) was employed. The samples were placed inside the SEM's vacuum column $\left(10^{-6}\right.$ Torr $)$ through an airtight door. Pollen species were also distinguished and countered under $3000 \times$ magnification and $15-20 \mathrm{kV}$ working conditions.

Calculation of the airborne asbestos fiber concentration on the filter sample was carried out using the following formula:

$$
F_{\text {con }}=\frac{A_{\text {eff }} \times N_{\text {total }}}{a_{\text {field }} \times n_{\text {field }} \times V_{\text {air }}}
$$

where $F_{c o n}$ is airborne fiber concentration (fiber/L, $\mathrm{f} \mathrm{L}^{-1}$ ), $A_{\text {eff }}$ is effective collecting area of filter $\left(\mathrm{cm}^{2}\right), N_{\text {total }}$ is the total number of fibers in an SEM field area, $a_{\text {field }}$ is an SEM field area $\left(\mathrm{cm}^{2}\right), n_{\text {field }}$ is total number of fields counted on the filter, and $V_{\text {air }}$ is total air volume (L) calculated by sample collection time (min) and pump flow rate $(\mathrm{L} / \mathrm{min})$.

The processes of classifying asbestos types based on the elemental wt\% data obtained from the SEM-EDX analysis is illustrated in Fig. 6. Palynologists rely on light microscopy (LM) to identify and interpret the pollen spectrum of a particular sample (Jones and Bryant, 2007). SEM is also used to identify pollen because of its increased resolution (Vezey et al., 1991). In this study, for the purpose of observing the morphological property of airborne pollen grains, an SEM (JEOL JSM-5400) was applied.

\section{RESULTS AND DISCUSSION}

\section{1 Spatial Distribution of $\mathbf{P M}_{2.5}$ and Major Water-soluble lons}

Air pollution, especially $\mathrm{PM}_{2.5}$, has become a serious issue in East Asia, and there is rising public criticism regarding its effects. Concern in Japan is also increas-

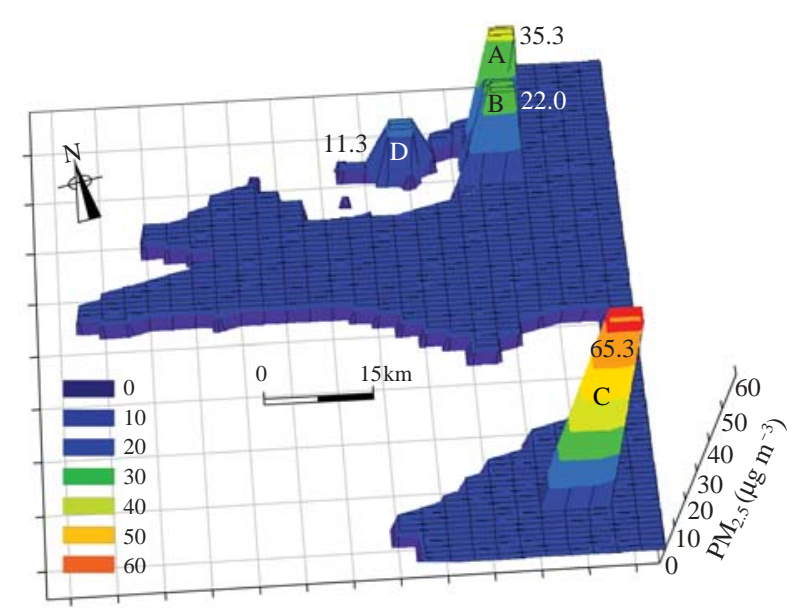

Fig. 3. 3D distribution of $\mathrm{PM}_{2.5}$ monitoring data at 4-sampling site.

ing as winds transfer the pollution into domestic areas. Fig. 3 shows the distribution of $\mathrm{PM}_{2.5}$ monitoring data at four-sampling sites (i.e., a heavy traffic area (A), a residential area (B), an industrial area (C), and a desolate area (D)). Site $\mathrm{C}$, an industrial area, showed the heighest $\mathrm{PM}_{2.5}\left(65.3 \mu \mathrm{g} \mathrm{m}^{-3}\right)$ followed by site $\mathrm{A}(35.3$ $\left.\mu \mathrm{g} \mathrm{m}^{-3}\right)$, site $\mathrm{B}\left(22.0 \mu \mathrm{g} \mathrm{m}^{-3}\right)$, and site $\mathrm{C}\left(11.3 \mu \mathrm{g} \mathrm{m}^{-3}\right)$. As might be expected, the highest $\mathrm{PM}_{2.5}$ level was monitored at site $\mathrm{C}$ where there is a compact mass of manufacturing companies. Among the four monitoring sites, two sites (i.e., site $\mathrm{A}$ and $\mathrm{C}$ ) exceeded the Japan's $\mathrm{PM}_{2.5}$ criteria (a daily average of $35 \mu \mathrm{g} \mathrm{m}^{-3}$ ). The reason for the relatively high $\mathrm{PM}_{2.5}$ in both heavy traffic and industrial areas might be that much of fine particles and their precursors came from the vehicle emissions and fuel combustion and manufacturing processes in factories. The $\mathrm{PM}_{2.5}$ data monitored in this study are compared with those measured in other urban and rural areas in Asia during the springtime. Zhang et al. (2006) reported that $\mathrm{PM}_{2.5}$ was $145.3 \mu \mathrm{g} \mathrm{m}^{-3}$ in Beijing during a non-Asian dust period in the springtime. Meanwhile, in Gosan, a typical rural area in Korea, $\mathrm{PM}_{2.5}$ during non-Asian dust period was measured at $26.1 \mu^{-3} \mathrm{~g}^{-3}$ (Stone et al., 2011).

It is a matter of course that a large number of factories contributed to the high $\mathrm{PM}_{2.5}$ level and caused the regional worsening air pollution in a residential area (B). However, although the "yellow dust" warning did not issue during our field measurement, there is a possibility of the long-range transport of $\mathrm{PM}_{2.5}$ and its precursors from the Asian continent to the local study site in Japan. Thus, it is required to clear the uncertainties regarding the linkage between locally high $\mathrm{PM}_{2.5}$ at site $\mathrm{C}$ and its long-range transport under the springtime meteological conditions. In this study, in order to deter- 

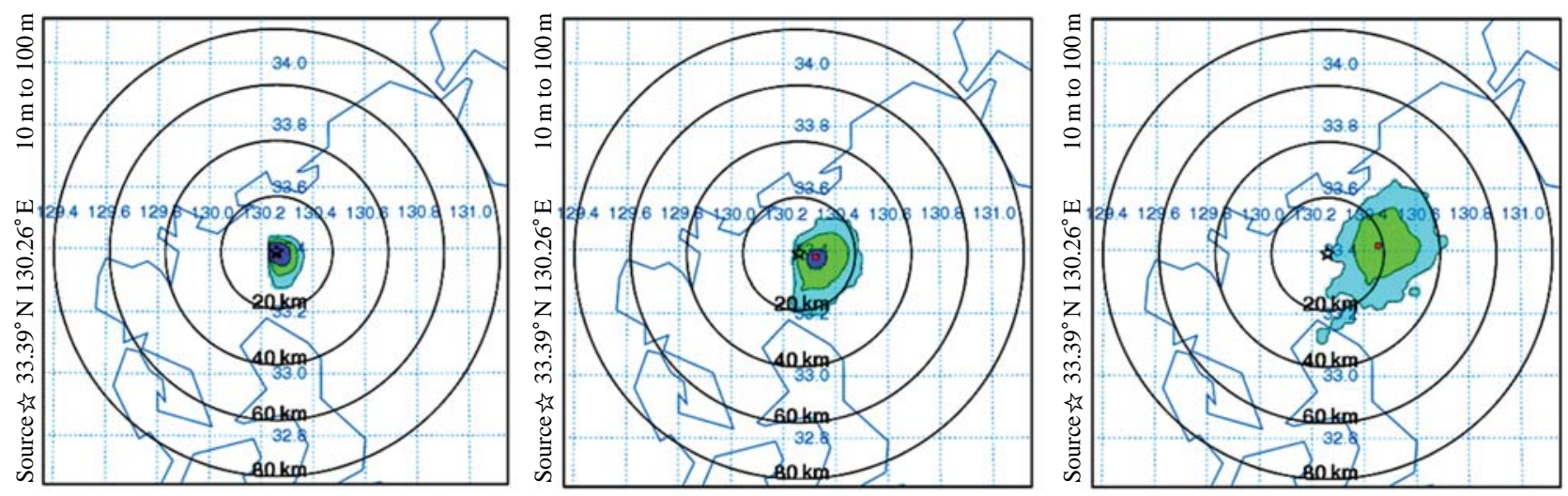

Fig. 4. Backward aerosol concentrations simulated by the NOAA ARL HYSPLIT model. The area scales mean the integrated mass concentration [mass $\mathrm{m}^{-3}$ ] at $10-100 \mathrm{~m}$ height of site $\mathrm{C}\left(33.39^{\circ} \mathrm{N} ; 130.26^{\circ} \mathrm{E}\right)$.

mine the source region of aerosols at the site $\mathrm{C}$, the atmospheric backward dispersion model was applied.

Fig. 4 displays the backward aerosol dispersion simulated by the NOAA Air Resources Laboratory (ARL) HYSPLIT dispersion-trajectory model started from site $\mathrm{C}$. The area scales mean the integrated mass concentration [mass $\mathrm{m}^{-3}$ ] at $100-1000 \mathrm{~m}$ height of site $\mathrm{C}$ $\left(33.39^{\circ} \mathrm{N} ; 130.26^{\circ} \mathrm{E}\right)$. A detailed model description of HYSPLIT was given by Rolph (2003). According to the result of the HYSPLIT model, a high value of aerosol concentration at the present receptor (measurement location) was not driven from the Chinese continent but was generated from a local area.

Ambient concentrations of major ionic species (i.e., nitrate, sulfate, and ammonium) associated with $\mathrm{PM}_{2.5}$ collected at four-sampling sites were overlapped with a map of Fukuoka Prefecture (Fig. 5). As shown in Fig. 5 , the concentrations of major ionic species turned out to be of considerable variation among four sites. Sulfate was the most abundant species to record the highest concentrations in all urban areas of Fukuoka Prefecture (a heavy traffic area $\left(14.1 \mu \mathrm{g} \mathrm{m}^{-3}\right)$, an industrial area $\left(30.5 \mu \mathrm{g} \mathrm{m}^{-3}\right)$, and a residential area $\left(2.8 \mu \mathrm{g} \mathrm{m}^{-3}\right)$. The sum concentrations of $\mathrm{NH}_{4}{ }^{+}, \mathrm{NO}_{3}{ }^{-}$, and $\mathrm{SO}_{4}{ }^{2-}$ varied in a similar way, as $\mathrm{PM}_{2.5}$ (i.e., site $\mathrm{C}(38.4 \mu \mathrm{g}$ $\left.\mathrm{m}^{-3}\right)>$ site $\mathrm{A}\left(18.3 \mu \mathrm{g} \mathrm{m}^{-3}\right)>$ site $\mathrm{D}\left(5.4 \mu \mathrm{g} \mathrm{m}^{-3}\right)>$ site $\left.\mathrm{B}\left(4.9 \mu \mathrm{g} \mathrm{m}^{-3}\right)\right)$. This suggests that the overwhelmingly high level of site $C$ should be associated with the local pollution emissions. In the case of site $\mathrm{C}$ and $\mathrm{A}$, the sum of three ionic components correspond to $58.8 \%$ and $51.8 \%$ of $\mathrm{PM}_{2.5}$, respectively. Therefore, it seems reasonable to say that $\mathrm{PM}_{2.5}$ in sites $\mathrm{C}$ and A was mainly composed by the secondary inorganic aerosol, which was formed by a gas-to-gas reaction in the atmosphere.

The concentrations of three kinds of ionic species in $\mathrm{PM}_{2.5}$ in this study are comparable to those of urban areas in Beijing, China, and Durg, India. Gao et al.

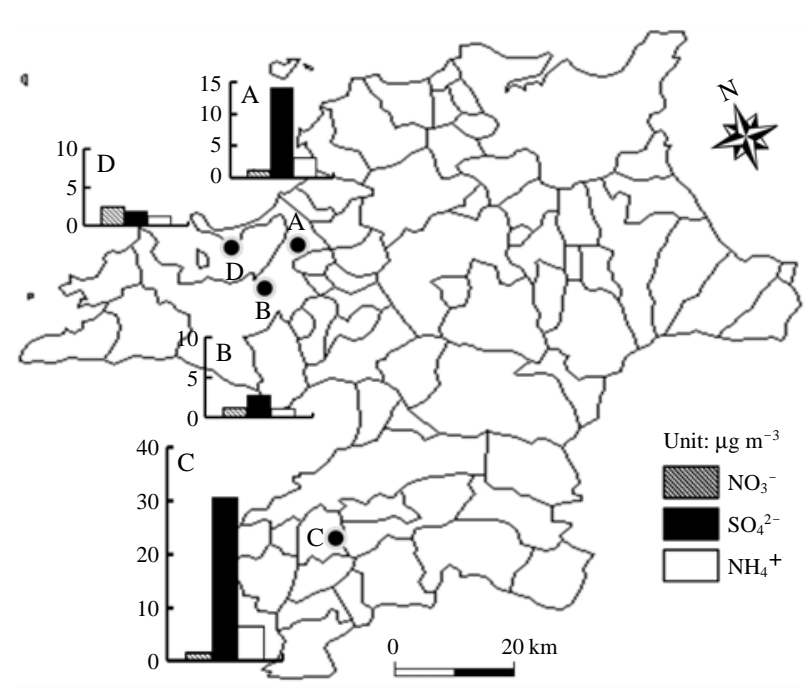

Fig. 5. Ambient concentrations of major water-soluble ions associated with $\mathrm{PM}_{2.5}$ collected at 4-sampling site in Fukuoka Prefecture.

(2013) reported that the concentrations of $\mathrm{NH}_{4}{ }^{+}, \mathrm{NO}_{3}{ }^{-}$, and $\mathrm{SO}_{4}{ }^{2-}$ in $\mathrm{PM}_{2.5}$ collected in Beijing were 20.5, 15.2, and $42.3 \mu \mathrm{g} \mathrm{m}^{-3}$, respectively. On the other hand, those concentrations in Durg, a heavy traffic and industrial area, were marked as $2.1,3.16$, and $6.75 \mu \mathrm{g} \mathrm{m}^{-3}$, respectively (Deshmukh et al., 2011). The occupation ratio of the sum concentration of three ionic components in this area $(0.89 \%)$ is greatly dissimilar to those of this study.

\section{2 Assessment of Airborne Asbestos Fiber}

Even though asbestos is closely regulated in the present, the deposited and accumulated asbestos fibers for the past several tens of years can be resuspended from the ground near the distributing and manufactur- 


\begin{tabular}{|c|c|c|c|c|c|c|c|c|c|c|}
\hline \multicolumn{5}{|c|}{$\begin{array}{l}\text { Raw data of SEM-EDX } \\
\text { wt } \% \text { of selected four-kind Z }\end{array}$} & \multicolumn{4}{|c|}{$\begin{array}{c}\text { Crocidolite } \\
\left(\mathrm{Na}(\mathrm{Fe}, \mathrm{Mg})_{3} \mathrm{Fe}_{2} \mathrm{Si}_{8} \mathrm{O}_{22}(\mathrm{OH}, \mathrm{F})_{2}\right) \\
\text { Relative } \mathrm{M} \cdot \mathrm{W} .(\%) \text { of } \\
\mathrm{Na}: \mathrm{Mg}: \mathrm{Si}: \mathrm{Fe} \\
=2.7: 8.3: 56.3: 31.7\end{array}$} & \multicolumn{2}{|c|}{$\begin{array}{c}\text { Amosite } \\
\left(\mathrm{Fe}_{7} \mathrm{Si}_{8} \mathrm{O}_{22}(\mathrm{OH})_{2}\right) \\
\text { Relative M.W. }(\%) \text { of } \\
\mathrm{Si}: \mathrm{Fe}=36.5: 63.5\end{array}$} \\
\hline Fiber & $\mathrm{Na}$ & $\mathrm{Mg}$ & $\mathrm{Si}$ & $\mathrm{Fe}$ & $\mathrm{Na}$ & $\mathrm{Mg}$ & $\mathrm{Si}$ & $\mathrm{Fe}$ & $\mathrm{Si}$ & $\mathrm{Fe}$ \\
\hline Fiber №.1 & 7.07 & 0.72 & 0.25 & 0.2 & 85.80 & 8.74 & 3.03 & 2.43 & 55.56 & 44.44 \\
\hline Fiber №.2 & 7.54 & 0.31 & 0.92 & 0.68 & 79.79 & 3.28 & 9.74 & 7.20 & 57.50 & 42.50 \\
\hline Fiber №.3 & 0.53 & 9.63 & 7.77 & 1.79 & 2.69 & 48.83 & 39.40 & 9.08 & 81.28 & 18.72 \\
\hline Fiber №.4 & 0.72 & 0.49 & 1.36 & 21.02 & 3.05 & 2.08 & 5.77 & 89.11 & 6.08 & 93.92 \\
\hline Fiber №.5 & 0.47 & 0 & 0.31 & 0.83 & 29.19 & 0.00 & 19.25 & 51.55 & 27.19 & 72.81 \\
\hline Fiber №.6 & 0.67 & 0.37 & 0.34 & 0.65 & 33.00 & 18.23 & 16.75 & 32.02 & 34.34 & 65.66 \\
\hline Fiber №.7 & 0.56 & 1.07 & 14.49 & 1.22 & 3.23 & 6.17 & 83.56 & 7.04 & 92.23 & 7.77 \\
\hline Fiber №.8 & 7.83 & 0.33 & 0.11 & 0.31 & 91.26 & 3.85 & 1.28 & 3.61 & 26.19 & 73.81 \\
\hline Fiber No.9 & 0.81 & 0.37 & 0.23 & 0.4 & 44.75 & 20.44 & 12.71 & 22.10 & 36.51 & 63.49 \\
\hline Fiber No.10 & 0.52 & 0.29 & 1.59 & 2.5 & 10.61 & 5.92 & 32.45 & 51.02 & 38.88 & 61.12 \\
\hline Fiber №.11 & 0.63 & 3.3 & 9.04 & 7 & 3.15 & 16.52 & 45.27 & 35.05 & 56.36 & 43.64 \\
\hline Fiber №.12 & 0.52 & 0.47 & 20.02 & 0.73 & 2.39 & 2.16 & 92.09 & 3.36 & 96.48 & 3.52 \\
\hline Fiber No.13 & 2.48 & 0.54 & 8.26 & 0.29 & 21.43 & 4.67 & 71.39 & 2.51 & 96.61 & 3.39 \\
\hline Fiber No.14 & 0.39 & 2.68 & 12.31 & 10.26 & 1.52 & 10.45 & 48.01 & 40.02 & 54.54 & 45.46 \\
\hline Fiber No.15 & 2.1 & 3.21 & 6.51 & 3.65 & 13.57 & 20.75 & 42.08 & 23.59 & 64.07 & 35.93 \\
\hline Fiber №.16 & 0.44 & 3.85 & 8.85 & 277 & 2.77 & 24.20 & 55.63 & 17.41 & 76.16 & 23.84 \\
\hline Fin... Mn 17 & 071 & $\underline{7.12}$ & 1026 & 5.5 .2 & $n 15$ & 23.91 & 55.01 & $m+n$ & $7 \Delta^{71}$ & 2536. \\
\hline & & $\longrightarrow$ & & & & Le & & & & \\
\hline & & - & & & & 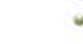 & & & & \\
\hline & & & & & Fin & identifie & & & Fine & identified \\
\hline & & & & & Mo & rately ide & & & Mod & tely identified \\
\hline
\end{tabular}

Fig. 6. Processes of asbestos identification by the elemental wt $\%$ obtained from SEM-EDX analysis.

ing shops of asbestos products.

Asbestos from natural geologic deposits is known as "naturally occurring asbestos" (NOA) (Interim Guidance, 2004). Health risks associated with exposure to NOA are not yet fully understood. As air quality associated with asbestos in ambient outdoor air has seldom been evaluated in Fukuoka Prefecture, we evaluated airborne asbestos in the urban environment there. Six mineral types are defined by the United States Environmental Protection Agency as asbestos (El Dorado County, 2003). Among them, crocidolite and amosite are commonly known to cause negative health effects such as lung cancer and mesothelioma (Camus et al., 1998).

Fig. 6 illustrates the number concentration of asbestos fiber (a sum of crocidolite $\left(\mathrm{Na}(\mathrm{Fe}, \mathrm{Mg})_{3} \mathrm{Fe}_{2} \mathrm{Si}_{8} \mathrm{O}_{22}\right.$ $\left.(\mathrm{OH}, \mathrm{F})_{2}\right)$ and amosite $\left(\mathrm{Fe}_{7} \mathrm{Si}_{8} \mathrm{O}_{22}(\mathrm{OH})_{2}\right)$ at four-sampling sites and distribution of point sources of asbestos fiber in Fukuoka Prefecture. The highest airborne asbestos fiber concentration was recorded at site $\mathrm{C}(14.4 \mathrm{f}$ $\left.\mathrm{L}^{-1}\right)$, followed by site $\mathrm{A}\left(5.9 \mathrm{f} \mathrm{L}^{-1}\right)$, site $\mathrm{D}\left(3.4 \mathrm{f} \mathrm{L}^{-1}\right)$, and site $\mathrm{B}\left(2.5 \mathrm{f} \mathrm{L}^{-1}\right)$. The average concentration of the airborne asbestos fiber at all sites was $6.14 \mathrm{f} \mathrm{L}^{-1}$. This average concentration level is similar to those ( 7 $\mathrm{f} \mathrm{L}^{-1}$ ) measured at asbestos abatement sites in Korea (Kim et al., 2009).

In 1989, the Japanese Air Pollution Control Law and related orders were revised to classify asbestos as a "specified dust" and to set up 10 fibers/liter (for including all type of asbestos) as the regulation guideline Concentration at the Boundary of the Asbestos Dusts Generation Facilities (i.e. asbestos products manufacturing facilities) (Japanese Situation on Asbestos, 2013). Asbestos fiber concentration of site $\mathrm{C}\left(14.4 \mathrm{f} \mathrm{L}^{-1}\right)$ is considerably higher than the regulated levels of asbestos of the Concentration Standard at the Boundary of the Asbestos Dusts Generation Facilities.

To explore the possible reasons for the high asbestos fiber concentration at site $\mathrm{C}$, the forecast atmospheric dispersion was simulated by the NOAA ARL Gaussian model. The map of the right bottom of Fig. 7 shows sampling site $\mathrm{C}$ as having a dense asbestos point source and the area distribution of the air flume started from intensively distributed companies producing asbestos related products. According to the result of NOAA's ARL Gaussian model, the C sampling site was in an downwind position. It is therefore suggested that the relative high asbestos concentration at site $\mathrm{C}$ 


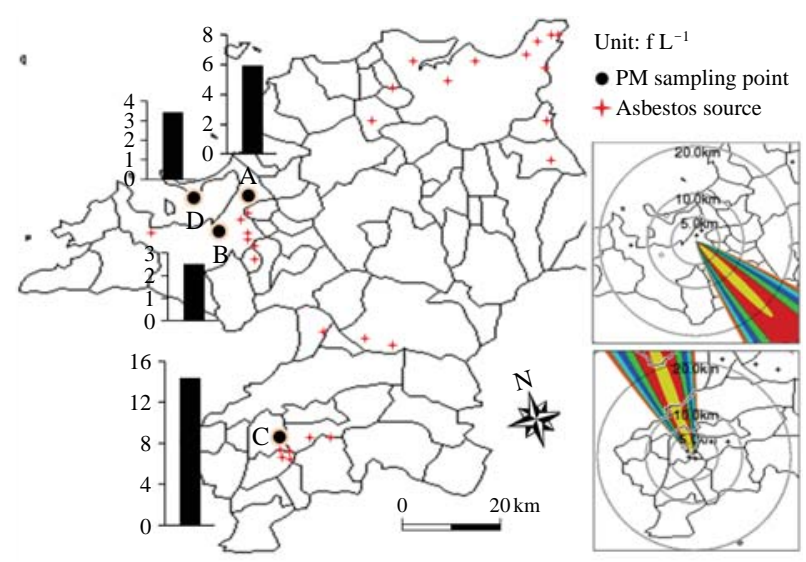

Fig. 7. Number concentration of asbestos fiber (crocidolite and amosite) at 4-sampling site and distribution of point sources of asbestos fiber in Fukuoka prefecture. Map showing sampling site $\mathrm{C}$ (right bottom) having dense asbestos point source and the area distribution of air flume started from the intensively distributed companies producing asbestos related products.

was strongly influenced by the clumped distribution of point sources of asbestos fiber. Meanwhile, although the concentration of asbestos measured at site A (heavy traffic area) was lower than the Concentration Standard at the Boundary of the Asbestos Dusts Generation Facilities, asbestos was detected at levels around 2 times higher than those of sites B and D.

NOAA's ARL Gaussian model shown in the right upper part of Fig. 7 indicates that the point sources of asbestos fiber situated densely near site A did not exert a direct influence on the asbestos concentration at site A. For several years, automobile parts that needed insulation from heat and friction were manufactured from dangerous asbestos, due to its excellent heatresistant qualities. Such parts included brake linings, clutch facings, transmission components, disc brake pads, drum brake linings, and brake blocks (Lemen, 2004).

According to both the result of NOAA's ARL Gaussian model (the right upper of Fig. 7) and the information on extensive use of asbestos in automobiles, the asbestos concentration at site A was probably affected by automobiles.

\section{3 Spatial Distribution of Ambient Pollen}

Fig. 8 shows the spatial variation of the number concentration of airborne pollen at the four sites in Fukuo$\mathrm{ka}$ Prefecture. There was a noticeable spatial difference in the concentrations among three pollen types. Cedar (Cryptomeria, also called the Sugi tree in Japanese) pollen was distributed in advance of other pollens at sites $\mathrm{A}, \mathrm{B}$, and $\mathrm{C}$, with the maximum concentration at

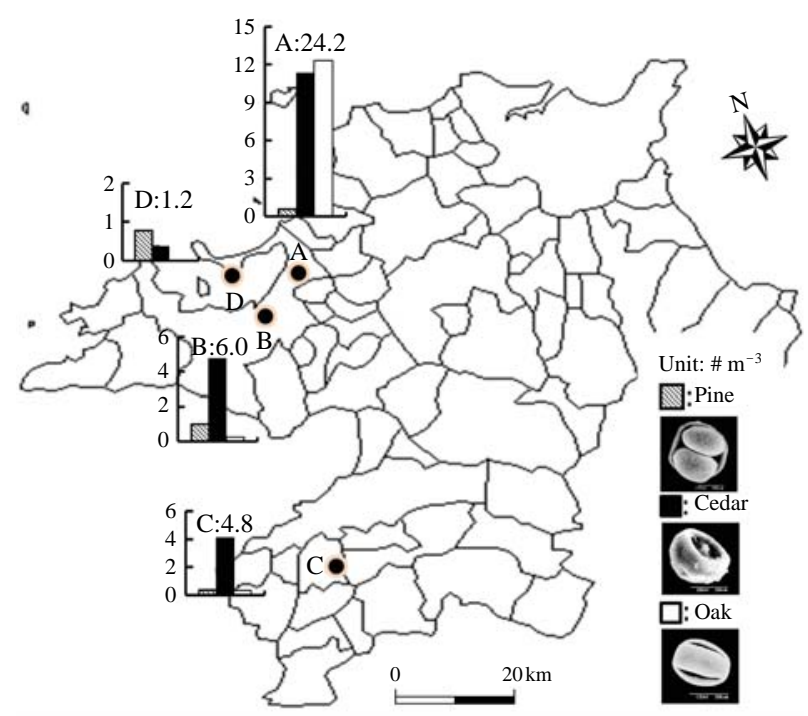

Fig. 8. Pollens number concentration at each sampling site.

site A. This cedar pollen is the most common allergen for seasonal allergic rhinitis in Japan. Cedar showed a higher concentration than other types of pollen and it was probably generated from the Sugi tree that is the most important timber tree in Japan.

The sum of the number concentration of three pollen types is still high at site A. Although the atmospheric presence of pollen grains is likely to vary depending on the local kind of plant, actual weather situations, and pollinating period, the vegetation of the surface is also important (Mandrioli et al., 1980). Cedar pollen easily absorbs water in the atmosphere and then settles down on surface. However, they can be easily resuspended into the atmosphere by the urban surface covered with asphalt and cement. Both hot-island and building wind can also promote the resuspension of pollen (Saito et al., 2006). Therefore, site A, with its relatively high pollen concentrations, was probably affected by the typical urban surface and local plant.

\section{CONCLUSIONS}

A better knowledge of the impact of both artificial and biological PM on urban atmosphere can help establish improved the management strategies of urban air quality. In this study, we made an attempt to provide an assessment of springtime air quality in the Fukuoka Prefecture, Japan through an intensive measurement of PM. The results of our intensive field measurement suggested that synergic biological effects induced by ambient allergenic pollen and urban fine PM in atmosphere are associated with a peculiar springtime air qua- 
lity in the Fukuoka Prefecture. Our study also indicates that the specific artificial and natural sources are regionally distributed to influence local air quality and public health. We should be mindful of the fact that in order to improve the understanding of urban air quality regarding the environmental load and repercussions on human health, it will be necessary to continue the monitoring of not only particulate matters but also gaseous materials.

\section{ACKNOWLEDGEMENT}

The HYSPLIT aerosol dispersion model (http://www. arl.noaa.gov/ready.html) developed by the National Oceanic Atmospheric Administration (NOAA) for backward trajectory was very helpful to data interpretation. The authors also express sincere thanks to Prof. G.-U. Kang, Department of Medical Administration, Wonkwang Health Science University for his ion analysis. The second author acknowledges support made by the Basic Science Research Program through the National Research Foundation of Korea (NRF) funded by the Ministry of Science, ICT and Future Planning (Grant No 2013-004624). This study was partially supported by funding from the Consortium of Asian Universities in Fukuoka (CAUFUK), Fukuoka Prefecture, Japan.

\section{REFERENCES}

Camus, M., Siemiatycki, J., Meek, M.Sc.B. (1998) Nonoccupational Exposure to Chrysotile Asbestos and the Risk of Lung Cancer. New England Journal of Medicine 338, 1565-1571.

Cook, P.M., Glass, G.E., Tucker, J.H. (1974) Asbestiform amphibole minerals: Detection and measurement of high concentrations in municipal water supplies. Science 185, 853-855.

Deshmukh, D.K., Deb, M.K., Tsai, Y.I., Mkoma, S.L. (2011) Water Soluble Ions in $\mathrm{PM}_{2.5}$ and $\mathrm{PM}_{1}$ Aerosols in Durg City, Chhattisgarh, India. Aerosol and Air Quality Research 11, 696-708.

El Dorado County (2003) Naturally occurring asbestos and dust protection http://www.co.el-dorado.ca.us/emd/ apcd/PDF/Naturally_Occuring_Asbestos_June_12.pdf.

Fukuoka Prefecture (2013) About Fukuoka http://www. pref.fukuoka.lg.jp/somu/multilingual/english/about. html.

Gao, X., Nie, W., Xue, L., Wang, T., Wang, X., Gao, R., Wang, W., Yuan, C., Gao, J., Ravi, K.P., Wang, J., Zhang, Q. (2013) Highly time-resolved measurements of secondary ions in $\mathrm{PM}_{2.5}$ during the 2008 Beijing Olympics: The impacts of control measures and region- al transport. Aerosol and Air Quality Research 13, 367376.

Interim Guidance (2009) Naturally occurring asbestos (NOA) at school sites http://www.dtsc. ca.gov/Schools/ upload/SMBRP_POL_Guidance_Schools_NOA.pdf.

Japanese situation on asbestos (2013) Issues and BANJAN's Activities, http://park3.wakwak.com/ banjan/main/ torikumi/html/issues.htm.

Jones, J.G., Bryant, V.M., Jr. (2007) A comparison of pollen counts: Light versus scanning electron microscopy. Grana 46, 20-33.

Kim, J.Y., Lee, S.K., Lee, J.H., Lim, M.H., Kang, S.W., Phee, Y.G. (2009). A study on the factors affecting asbestos exposure level from asbestos abatement in building demolition sites. Korean Industrial Hygiene Journal 19, 8-15.

Lemen, R.A. (2004) Asbestos in brakes exposure and risk of disease. American Journal of Industrial Medicine, 45, 229-237.

Mandrioli, P., Negrini, M.G., Scarani, C., Tampieri, F., Trombetti, F. (1980) Mesoscaletransportof Coryluspollengrainsinwinteratmosphere. Grana 19, 227-233.

Monthly Archives (2013) More than surface deep-check your soil for asbestos http://www.asbestosremovalsaustralia.com.au/blog/2013/04/.

Nussbaum, Louis-Frédéric (2005) Fukuoka-ken in Japan Encyclopedia 218-219.

Rolph, G.D. (2003) Real-time Environmental Applications and Display System (READY), NOAA Air Resources Laboratory http://www.arl.noaa.gov/ready/hysplit4. html.

Saito, Y., Ide, T., Murayama, K. (2006) Science of pollenosis. Kagakudouzinn co. pp. 14-42.

Schwartz, J., Neas, L.M. (2000) Fine particles are more strongly associated than coarse particles with acute respiratory health effects in schoolchildren. Epidemiology 11, 6-10.

Stone, E.A., Yoon, S.C., Schauer, J.J. (2011) Chemical characterization of fine and coarse particles in Gosan, Korea during springtime dust events. Aerosol and Air Quality Research 11, 31-43.

Takahashi, Y., Tokumam, K., Kawashima, S. (1992) Distribution chart of Cryptomeria japonica forest through data analysis of landsat-TM. Japanese Journal of Palynology 38, 140-147.

Vezey, E.L., Skvarla, J.J., Vanerpool, S.S. (1991). Characterizing pollen sculpture of three closely-related Capparaceae species using quantitative image analysis of scanning electron micrographs, Clarendon Press, Oxford, 44, pp. 291-300.

Zhang, W.J., Sun, Y.L., Zhuang, G.S., Xu, D.Q. (2006) Characteristics and seasonal variations of $\mathrm{PM}_{2.5}, \mathrm{PM}_{10}$, and TSP aerosol in Beijing. Biomedical and Environmental Sciences 19, 461-468.

(Received 30 October 2013, revised 6 December 2013, accepted 16 December 2013) 